\title{
Improving Outcomes for Elderly Patients Following Emergency Surgery: a Cutting-edge Review
}

\author{
James M. Halle-Smith ${ }^{1}$ - David N. Naumann ${ }^{1}$ - Susan L. Powell ${ }^{2}$ - Laura K. Naumann ${ }^{3}$ Ewen A. Griffiths ${ }^{1,4,5}$
}

Accepted: 2 November 2021 / Published online: 25 November 2021

(c) The Author(s) 2021

\begin{abstract}
Purpose of Review The aim of this review is to explore the consequence of emergency general surgery in the elderly, and to summarise recent developments in the pre-, peri- and postoperative management of these patients, in order to improve outcomes. Recent Findings Preoperatively, accurate risk assessment is vital to ensure the right patients undergo emergency surgery. Perioperatively, there are multiple interventions specific to elderly patients that have been shown to improve outcomes. Postoperatively, elderly patients must be cared more in an appropriate setting in order to avoid failure to rescue and promote return to function.

Summary This review of contemporary evidence identifies multiple pre-, peri- and postoperative interventions that can improve outcomes for elderly patients after emergency general surgery. These evidence-based recommendations should help direct care of elderly patients undergoing emergency surgery and foster further quality improvement measures and research investigations.
\end{abstract}

Keywords Elderly $\cdot$ Emergency surgery $\cdot$ Outcomes $\cdot$ Service improvement

\section{Introduction}

Mortality from conditions requiring emergency surgery remains significantly high [1-3],contributing $28 \%$ of deaths worldwide $[4,5]$. This is in part due to a globally ageing

This article is part of the Topical Collection on Geriatric Anesthesia

Ewen A. Griffiths

ewen.griffiths@uhb.nhs.uk

1 Department of Surgery, Queen Elizabeth Hospital Birmingham, University Hospitals Birmingham NHS Trust, Birmingham, UK

2 Department of Elderly Care, Worcester Royal Hospital, Charles Hastings Way, Worcester WR5 1DD, UK

3 Department of Anaesthesia, Queen Elizabeth Hospital Birmingham, University Hospitals Birmingham NHS Trust, Birmingham, UK

4 Department of Upper Gastrointestinal Surgery, Queen Elizabeth Hospital Birmingham, University Hospitals Birmingham NHS Trust, Birmingham, UK

5 Institute of Cancer and Genomic Sciences, College of Medical and Dental Sciences, University of Birmingham, Birmingham, UK population, meaning that patients requiring emergency general surgery are frequently presenting with an increased disease burden, which provides more challenges to both clinicians and health care resources $[1,3]$. In the United Kingdom, the National Emergency Laparotomy Audit (NELA) has reported that $56 \%$ of patients undergoing emergency laparotomy are over the age of 65 years old[6]. It is likely that this number will continue to increase, since the proportion of the population aged 85 years and over is projected to double over the next 25 years in the United Kingdom (UK) [7]. Any efforts to improve emergency general surgical care for patients must therefore address pre-, peri- and postoperative care for the elderly.

Emergency general surgery in the elderly presents many challenges. With advancing age, the prevalence of comorbidity and polypharmacy increases [8-11], and patients are less likely to possess the physiological reserve required to withstand a major operative intervention or postoperative

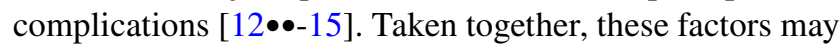
result in increased perioperative morbidity and mortality rates in this population group [13-18].

Frailty has been defined as a cumulative decline in many physiological systems during a lifetime, which in turn depletes homeostatic reserves meaning that even minor 
physically stressful events can trigger disproportionate changes in health status $[9 \bullet \bullet, 17]$. As a result, frailty is increasingly recognised as a significant risk factor for mortality after emergency surgery, both in the immediate postoperative phase $[12 \bullet \bullet, 19]$ and in the longer term $[12 \bullet \bullet, 20]$. It is also known that the accurate assessment of frailty can help clinicians to make appropriate treatment decisions for elderly patients in emergency situations $[8 \bullet, 21]$, thereby aiding the decision-making process for patients and their families [8•, 21]. However, despite this evidence-based importance of frailty assessment, the most recent NELA report found that only $28.8 \%$ of patients with frailty over 65 were reviewed by a consultant geriatrician [6].

The aim of this review is to explore the consequence of emergency general surgery in the elderly, and to summarise recent developments in the pre-, peri- and postoperative management of these patients, in order to improve outcomes. These evidence-based recommendations should help direct care of elderly patients undergoing emergency surgery and foster further quality improvement measures and research investigations.

\section{Preoperative Assessment of Risk}

Preoperative identification of high-risk patients allows for both individualised perioperative care and more accurate counselling and decision-making [20,22]. In contrast to elective care, this has to be achieved rapidly, and therefore, standard preoperative investigations (such as lung function, echocardiography or cardiopulmonary exercise testing) are not feasible. Historically, risk assessment was undertaken using clinical judgement, which may vary greatly depending on individual experience or speciality background. Such an approach is also inherently at risk of bias and inaccuracy for the acutely unwell elderly patient for whom it is challenging to assess baseline function. As a result, risk assessment tools have become more favoured because they provide an objective quantitative risk prediction using evidence-based patient demographics, biomarkers and indications of physiological derangement [22, 23•].

The most frequently studied risk assessment tools for emergency laparotomy patients is the Physiological and Operative Severity Score for the enumeration of Mortality (POSSUM) scoring system [24, 25]. For patients who require admission to intensive care unit (ICU), the Acute Physiology And Chronic Health Evaluation (APACHEII) [26] has been used for some years for risk prediction during their stay in ICU $[22,23 \bullet]$. These scoring systems have been shown to be helpful in assessing the naturally heterogenous population undergoing emergency laparotomy $[22,23 \bullet]$ but may be too crude for risk stratification in the elderly population where comorbidity and frailty are more prevalent. It is therefore recommended that surgeons use the more recent NELA risk prediction score (https://data.nela.org.uk/riskcalculator/) which is based on the data of over 70,000 patients from the UK's NELA database $[27,28]$. A NELA risk of mortality score of $5 \%$ or higher has been used as a trigger to prompt postoperative admission to a high-dependency unit (HDU) (level 2) or ICU (level 3), which may also help to improve care for this population.

None of these commonly used risk calculators incorporates a specific frailty assessment, which in elective settings usually involves a thorough assessment with recommended tool such as the PRISMA questionnaire or timed-up-and-go test [29]. Given that frailty is now known to be a significant predic-

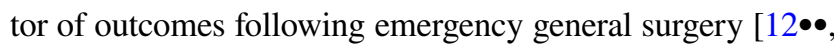
$19,20]$, an accurate preoperative frailty assessment is vital but not without difficulty in the emergency setting. Patients are acutely unwell, so it may be impossible to ascertain their baseline function, and staff may be under considerable time pressure. Relatives may also not be readily available for full discussion of prior function and capabilities. Recently, Rockwood's Clinical Frailty Score (CFS) has been proposed as a user-friendly way of objectively defining frailty and is both accurate in predicting postoperative outcomes $[12 \bullet \bullet, 23 \bullet]$ and can be completed in less than $60 \mathrm{~s}$ [29] (Fig. 1).

\section{Preoperative Optimisation of Comorbidities}

Elderly patients undergoing emergency general surgery are more likely to present with comorbidities and multiple regular medications compared to the younger population. It is important that these comorbidities are assessed accurately and optimised where possible in the preoperative period [30]. That said, it is widely accepted that surgery should only be delayed if the benefits of additional medical treatment outweigh the risks of delaying operative intervention [31]. Guidance from the Association of Anaesthetists clarifies this further by detailing seven appropriate reasons for delaying surgery which includes significant anaemia or electrolyte derangement, uncontrolled diabetes, acute onset left ventricular failure or reversible coagulopathy [31]. There is also guidance from the Association of Anaesthetists of Great Britain and Ireland (AAGBI) that set out a range of strategies from initial emergency care to anaesthetic room which can minimise risks to elderly patients undergoing emergency general surgery. These are summarised in Fig. 2 [29, 30, 32-37].

\section{Suitability of Surgery}

Even with the assistance of specialist advice and objective risk scoring systems, the decision to proceed to emergency surgery remains a complex one. A recent study indicated 
Fig. 1 Rockwood CFS and its effect on estimated mortality risk for different operative interventions according to NELA risk calculator [28]
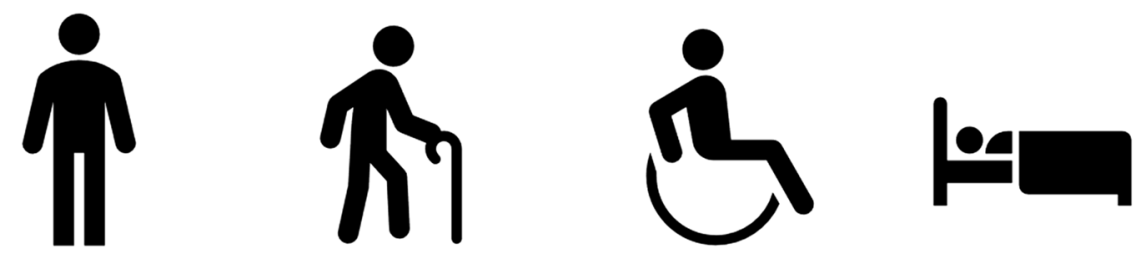

\begin{tabular}{|c|c|c|c|c|c|c|c|c|}
\hline $\begin{array}{c}1 \\
\text { Very Fit } \\
\text { Among }\end{array}$ & $\begin{array}{c}2 \\
\text { Well } \\
\text { No active }\end{array}$ & $\begin{array}{c}3 \\
\text { Managing } \\
\text { Well }\end{array}$ & $\begin{array}{c}4 \\
\text { Vulnerable } \\
\text { Symptoms }\end{array}$ & $\begin{array}{c}5 \\
\text { Mildly } \\
\text { Frail }\end{array}$ & $\begin{array}{c}6 \\
\text { Moderately } \\
\text { Frail }\end{array}$ & $\begin{array}{c}7 \\
\text { Severely } \\
\text { Frail }\end{array}$ & $\begin{array}{c}8 \\
\text { Very } \\
\text { Severely Frail }\end{array}$ & $\begin{array}{c}9 \\
\text { Terminally } \\
\text { III }\end{array}$ \\
\hline $\begin{array}{l}\text { fittest for } \\
\text { their age. } \\
\text { Exercise } \\
\text { regularly }\end{array}$ & $\begin{array}{l}\text { disease } \\
\text { symptoms. } \\
\text { Active } \\
\text { occasionally }\end{array}$ & $\begin{array}{l}\text { Medical } \\
\text { problems } \\
\text { well } \\
\text { controlled. } \\
\text { Not regularly } \\
\text { active }\end{array}$ & $\begin{array}{c}\text { limit } \\
\text { activity. } \\
\text { Feel } \\
\text { 'slowed up' }\end{array}$ & $\begin{array}{l}\text { Some } \\
\text { limitation on } \\
\text { shopping or } \\
\text { walking } \\
\text { outside }\end{array}$ & $\begin{array}{l}\text { Require help } \\
\text { with outside } \\
\text { activity and } \\
\text { personal } \\
\text { care. }\end{array}$ & $\begin{array}{l}\text { Completely } \\
\text { dependent } \\
\text { for personal } \\
\text { care. }\end{array}$ & $\begin{array}{l}\text { Completely } \\
\text { dependent, } \\
\text { may not } \\
\text { survive } \\
\text { minor illness }\end{array}$ & \\
\hline
\end{tabular}

\begin{tabular}{|l|l|c|c|c|}
\hline Intervention & Example & $\begin{array}{c}\text { Estimated Mortality } \\
\text { Risk } \\
\text { CFS 3-4 }\end{array}$ & $\begin{array}{c}\text { Estimated Mortality } \\
\text { Risk } \\
\text { CFS 5-6 }\end{array}$ & $\begin{array}{c}\text { Estimated Mortality } \\
\text { Risk } \\
\text { CFS 7-8 }\end{array}$ \\
\hline $\begin{array}{l}\text { Urgency: } 2 \mathrm{~A} \\
\text { Operative } \\
\text { severity: } \\
\text { Major }\end{array}$ & $\begin{array}{l}\text { Small } \\
\text { bowel } \\
\text { resection } \\
\text { for } \\
\text { obstruction }\end{array}$ & $2.1 \%$ & $12.1 \%$ & $27.7 \%$ \\
\hline $\begin{array}{l}\text { Urgency: } 2 \mathrm{~A} \\
\text { Operative } \\
\text { severity: } \\
\text { Major+ }\end{array}$ & $\begin{array}{l}\text { Laparotomy } \\
\text { for colonic } \\
\text { perforation }\end{array}$ & $2.5 \%$ & $13.8 \%$ & $30.8 \%$ \\
\hline $\begin{array}{l}\text { Urgency: } 1 \\
\text { Operative } \\
\text { severity: } \\
\text { Major+ }\end{array}$ & $\begin{array}{l}\text { Laparotomy } \\
\text { for GI } \\
\text { bleeding }\end{array}$ & $2.8 \%$ & $15.5 \%$ & \\
\hline
\end{tabular}

that a third of patients deemed eligible for laparotomy do not undergo surgery [38]. It is therefore important that clinicians are cognisant of the non-operative management strategies available for common surgical emergencies, for example radiological drainage for diverticular abscesses or endovascular aortic aneurysm repair [8 $\bullet$. The most common reason for non-operative management was a perceived lack of fitness for exploratory laparotomy, with

\begin{tabular}{|c|c|c|c|}
\hline $\begin{array}{l}\text { Pre-Hospital/ Emergency } \\
\text { Department }\end{array}$ & Preoperative Assessment & Preoperative Optimisation & $\begin{array}{l}\text { Extra Steps for Preoperative } \\
\text { Surgical Safety Checklist }\end{array}$ \\
\hline $\begin{array}{l}\text { Analgesia } \\
\text { - } \quad \text { Avoid NSAIDs } \\
\text { - } \quad \begin{array}{l}\text { Record time and dosage of } \\
\text { opioid analgesia }\end{array} \\
\text { administered } \\
\text { - } \quad \begin{array}{l}\text { Entonox and paracetamol } \\
\text { recommended }\end{array} \\
\text { Maintenance of Homeostasis } \\
\text { - } \quad \text { Avoidance of hypothermia } \\
\text { - Conservative fluid } \\
\quad \text { administration } \\
\text { Establish Premorbid Function } \\
\text { - From relatives or carers at } \\
\text { scene }\end{array}$ & $\begin{array}{l}\text { Undertake Anaesthesia- } \\
\text { Specific Geriatric } \\
\text { Assessment } \\
\text { - Ideally by geriatrician and } \\
\text { anaesthetic consultant with } \\
\text { experience in geriatric } \\
\text { anaesthesia }\end{array}$ & $\begin{array}{l}\text { Reduce Perioperative } \\
\text { Ischaemia Risk } \\
\text { - } \quad \begin{array}{l}\text { Improve oxygen delivery } \\
\text { (oxygen therapy, fluid }\end{array} \\
\text { resuscitation and avoid } \\
\text { hypotension) } \\
\text { - } \quad \text { Reduce oxygen } \\
\text { consumption } \\
\text { (thermoregulation, } \\
\text { analgesia, antibiotics) } \\
\text { Evidence-Based Management } \\
\text { of Organ-Specific Morbidity } \\
\text { - } \quad \text { E.g. diabetes, COPD, } \\
\text { ischaemic heart disease } \\
\text { and anaemia }\end{array}$ & $\begin{array}{l}\text { Sign in } \\
\text { - } \quad \text { Have vital signs been } \\
\text { - } \quad \text { Is the patient's resuscitation } \\
\text { status known? } \\
\text { - Does the patient have any } \\
\text { dentures? } \\
\text { - Does the patient have any } \\
\text { perioperative pressure } \\
\text { sores? } \\
\text { Has the site of any nerve } \\
\text { block been confirmed and } \\
\text { marked? } \\
\text { Time out } \\
\text { - Have possible areas of } \\
\text { pressure damage been } \\
\text { padded? } \\
\text { What is the patient's } \\
\text { haemoglobin } \\
\text { concentration? } \\
\text { - What is the patient's } \\
\text { eGFR? }\end{array}$ \\
\hline
\end{tabular}

Fig. 2 Recommendations for management of elderly patients before emergency surgery [29, 30, 32-37] 
the main factors involved in the decision-making process being age, renal function, albumin levels and the degree of physiological derangement, specifically raised lactate levels [38]. All of these measures have been associated with increased postoperative mortality $[39,40]$, so their increasing prevalence amongst elderly patients means that it is inevitable that for some of the elderly population emergency, surgical management will unfortunately be futile. For these patients, clinicians should ensure that specialist palliative care teams are involved soon after the decision for palliative treatment has been made [38, 41].

For elderly patients for whom surgery is felt to be appropriate, there are important extra considerations that need to be taken into account during preoperative counselling [30, 42]. Although death is a rare complication of emergency surgery in those with a good functional status, the risk cannot be ignored, and it is suggested that resuscitation status be part of the WHO checklist prior to surgery [43]. Indeed, the British Medical Association (BMA), Resuscitation Council UK and Royal College of Nurses have recently updated their guidance surrounding Do Not Attempt Resuscitation (DNAR) decisions to reflect this $[44,45]$. Furthermore, given that dementia and delirium are more common amongst elderly patients, care providers should ensure that patients and their families are made aware of the extra considerations that may be required to manage these patients perioperatively and the legal frameworks that apply locally $[42,46]$. An example of such considerations in the United Kingdom is deprivation of liberty safeguards (DoLS), which may be required should chemical or physical restraint be required for patient safety [46].

\section{Intraoperative Management}

Intraoperatively, elderly patients are at increased risk of hypotension and hypothermia [43]. To avoid hypotension, the AAGBI suggest a low threshold for use of invasive blood pressure monitoring and targeted fluid therapy. Elderly patients often have poorly compliant cardiac ventricles and vasculature [43, 47], and monitoring the depth of anaesthesia may avoid unintentional overdose of anaesthetic agents and associated hypotension [30, 43, 48]. Analgesia should be approached in a multimodal manner with the aim of avoiding excessive opiate consumption, which is associated with increased incidence of hypotension and delirium in this group of patients [43]. For example, administration of local anaesthesia through rectus sheath catheters has been shown to be as effective as epidural analgesia and reduce opiate usage after laparotomy $[49,50]$.

Hypothermia is common amongst elderly patients undergoing emergency surgery and can increase the incidence of postoperative delirium, cardiac dysfunction and poor wound healing $[43,51,52]$. Elderly patients' temperature should be monitored throughout the perioperative period, including during transport to and from the operating room, and within postoperative recovery areas $[43,51,52]$.

It has been proposed that an additional domain within the WHO 'sign out' checklist might be used to prompt the team to consider key issues specific to the elderly emergency surgery population, such as scoring systems to determine their postoperative level of care (ICU, HDU or ward-based care), fluid requirements, DNAR status and temperature [43]. A summary of the main recommendations from the AAGBI for the intraoperative management of elderly patients is presented in Fig. 3 . Further information is available from the AAGBI guidance [30].

\section{Postoperative Management}

It is vital that elderly patients are managed in a suitable location after emergency general surgery and that this decision is

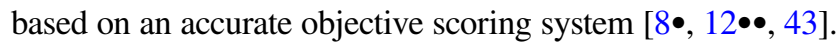
The introduction of post anaesthesia care units (PACUs) allows high-risk patients to be managed in a level 2 or 3 setting by staff specialised in postoperative care $[43,53,54]$. Such units facilitate early recognition and treatment of complications with close monitoring as well as optimum pain control in the perioperative period [43, 53, 54], especially important for elderly patients after emergency general surgery given their reduced physiological reserve and increased risk of delirium $[8 \bullet, 9 \bullet \bullet, 12 \bullet \bullet, 43]$.

\section{Recognition and Treatment of Postoperative Complications}

It has been shown that elderly emergency surgery patients are at most risk immediately after transfer to the ward from

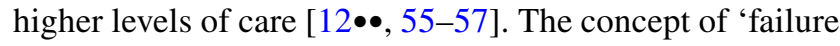
to rescue' refers to a potentially treatable or avoidable postoperative complication that leads to a patient's death $[8 \bullet$, 58]. This is more common amongst the elderly population where recognition of potentially treatable complications, such as anastomotic leak or pulmonary infection, is more difficult $[8 \bullet, 58]$. Early review by geriatricians in a 'stepdown' manner at this crucial time could help to reduce risk, given that they are trained in detecting and managing illness in this complex patient group. Furthermore, teams caring for these patients in the postoperative period should be encouraged to undertake close observation and have a low threshold for early CT scanning if a complication is suspected. In addition, centres should be able to provide non-operative management for postoperative complications, such as drainage of collections. 
Fig. 3 AAGBI recommendations for intraoperative management of elderly patients during emergency surgery [43]

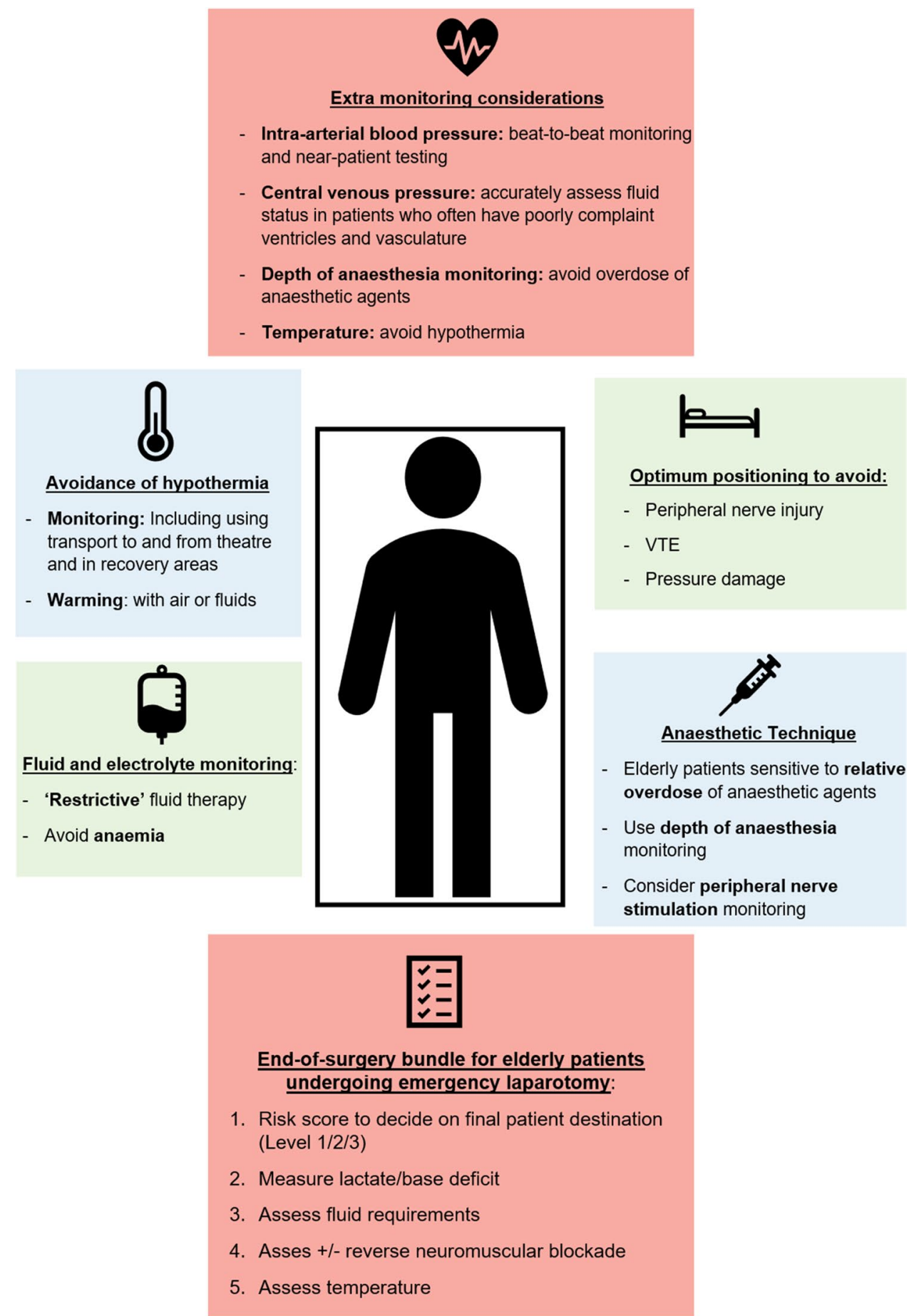

\section{Return to Function}

Once elderly patients have been stabilised on the ward after an emergency general surgical intervention, it is crucial to facilitate their return to baseline function for discharge. For this, it is vital to engage with all multidisciplinary team members to ensure that the patient's physical condition is optimised, for example by ensuring sufficient nutritional intake by liaising with dieticians $[9 \bullet \bullet, 43]$ and reducing loss of muscle mass with early involvement of physiotherapists [9••] (Fig. 4). Furthermore, specialist nurses play a vital role in disease-specific education and occupational therapists are crucial to ensuring coordinated discharge, which in the case of elderly patients can often be extremely complex and may require liaison with rehabilitation facilities $[59,60]$

For elderly patients admitted as an emergency, there is level 1 evidence demonstrating that a comprehensive geriatric 


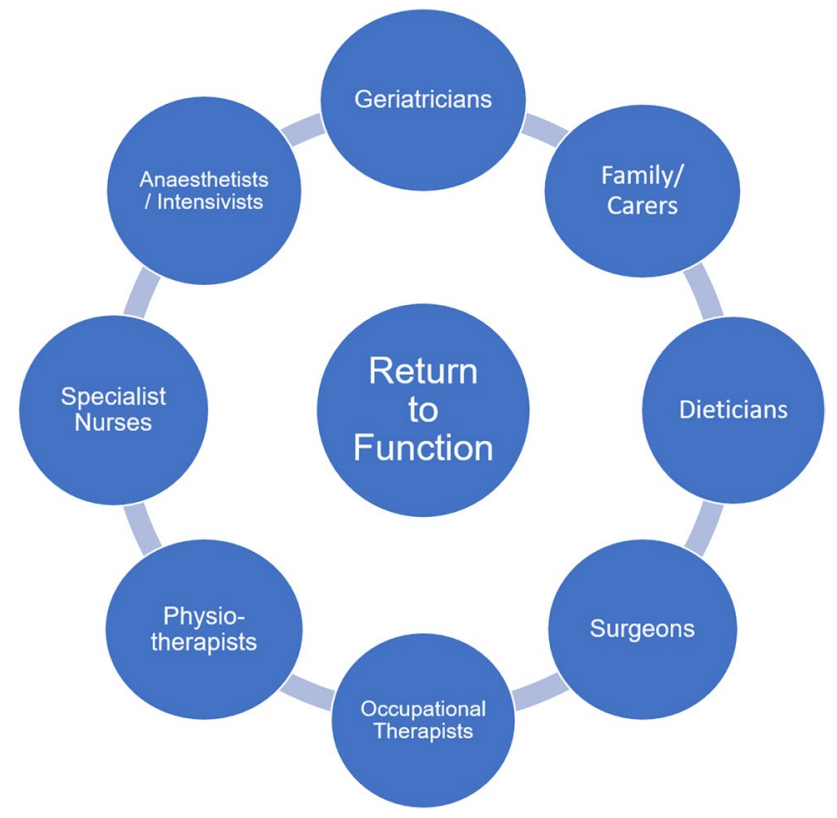

Fig. 4 Multidisciplinary team approach to return to function for elderly patients after emergency surgery

assessment performed by trained geriatricians increases both survival and chances of patients being discharged to their own homes [8・, 33, 59, 61]. A specific example of this is the success of orthogeriatricians managing elderly patients after orthopaedic surgery [62,63]. It is thought that this success is due to a greater understanding of age-related physiology and functional assessment for elderly patients which is not covered by standard internal medicine training [8•, 60, 62]. In terms of a model of care, it is recommended that the elderly care team is involved consistently throughout an elderly patient's emergency admission as opposed to being requested on an as required basis [59, 62]. Whilst this may be more resource intensive in the short term, it has been shown to reduce the length of stay and increase the proportion of patients discharged to their own homes [64-66], thereby reducing costs in the long term by reducing need for social care and accommodation [67].

\section{Future Directions}

Sarcopenia is an objective factor that can be measured on CT scans and is related to both frailty and postoperative outcome [23•]. Given the widespread use of cross-sectional imaging in emergency general surgery, most patients will have a scan from which sarcopenia may be assessed. Therefore, this may be used in addition to the CFS to further assess a patient's physical condition. The main issue at present is the lack of capability to assess sarcopenia quickly but with the development of machine learning algorithms, this may soon become available to clinicians [68].

There is evidence to suggest that modified enhanced recovery after surgery (ERAS) pathways can improve outcomes after emergency surgery. This is limited by the fact that these pathways have only been evaluated in retrospective studies, where complex cases such as bowel perforations and obstructing cancers were often excluded [69•, 70-74]. However, these initial promising results suggest that, in suitable patients, modified ERAS pathways can reduce length of stay and complications associated with delayed mobilisation after emergency general surgery [70-75].

Formal targeted training for both surgical and geriatric trainees in the multidisciplinary management of elderly patients after emergency general surgery would facilitate earlier detection and treatment of postoperative complications as well as return to function for discharge $[8 \bullet, 9 \bullet \bullet$, $11,76]$.

\section{Conclusions}

The proportion of elderly patients requiring emergency general surgery in the future is likely to continue to increase. This review of contemporary evidence identifies multiple pre-, peri- and postoperative interventions that can improve outcomes for elderly patients after emergency general surgery.

\section{Declarations}

Human and Animal Rights and Informed Consent This article does not contain any studies with human or animal subjects performed by any of the authors.

Conflict of Interest The authors do not have any potential conflicts of interest to disclose.

Open Access This article is licensed under a Creative Commons Attribution 4.0 International License, which permits use, sharing, adaptation, distribution and reproduction in any medium or format, as long as you give appropriate credit to the original author(s) and the source, provide a link to the Creative Commons licence, and indicate if changes were made. The images or other third party material in this article are included in the article's Creative Commons licence, unless indicated otherwise in a credit line to the material. If material is not included in the article's Creative Commons licence and your intended use is not permitted by statutory regulation or exceeds the permitted use, you will need to obtain permission directly from the copyright holder. To view a copy of this licence, visit http://creativecommons.org/licenses/by/4.0/. 


\section{References}

Papers of particular interest, published recently, have been highlighted as:

- Of importance

$\bullet$ Of major importance

1. Stewart B, Khanduri P, McCord C, et al. Global disease burden of conditions requiring emergency surgery. Br J Surg. 2013;101(1):e9-22. https://doi.org/10.1002/bjs.9329.

2. Tan BHL, Mytton J, Al-Khyatt W, et al. A comparison of mortality following emergency laparotomy between populations from New York State and England. Ann Surg. 2017;266(2):280-6. https://doi.org/10.1097/SLA.0000000000001964.

3. Wohlgemut JM, Ramsay G, Jansen JO. The changing face of emergency general surgery. Ann Surg. 2020;271(3):581-9. https://doi.org/10.1097/SLA.0000000000003066.

4. Meara JG, Leather AJM, Hagander L, et al. Global Surgery 2030: evidence and solutions for achieving health, welfare, and economic development. Lancet. 2015;386(9993):569-624. https://doi.org/10.1016/S0140-6736(15)60160-X.

5. Shrime MG, Sleemi A, Ravilla TD. Charitable platforms in global surgery: a systematic review of their effectiveness, costeffectiveness, sustainability, and role training. World J Surg. 2015;39(1):10-20. https://doi.org/10.1007/s00268-014-2516-0.

6. Reports - The National Institute of Academic Anaesthesia. https://www.nela.org.uk/reports. Accessed January 18, 2021.

7. National population projections - Office for National Statistics. https://www.ons.gov.uk/peoplepopulationandcommunity/popul ationandmigration/populationprojections/bulletins/nationalpo pulationprojections/2018based. Accessed January 18, 2021.

8. Torrance ADW, Powell SL, Griffiths EA. Emergency surgery in the elderly: challenges and solutions. Open Access Emerg Med. 2015. https://doi.org/10.2147/OAEM.S68324. This review article summarises different treatment modalities available for emergency surgical conditions in the elderly.

9.•• Parmar KL, Law J, Carter B, et al. Frailty in older patients undergoing emergency laparotomy. Ann Surg. 2019. https://doi. org/10.1097/sla.0000000000003402. This large, multicenter, study reports the relationship between frailty and outcomes after emergency laparotomy. It indicates the importance of measuring frailty using Clinical Frailty Score, opposed to making assumptions based on age alone.

10. Moug SJ, Stechman M, McCarthy K, Pearce L, Myint PK, Hewitt J. Frailty and cognitive impairment: unique challenges in the older emergency surgical patient. Ann R Coll Surg Engl. 2016. https://doi.org/10.1308/rcsann.2016.0087.

11. Pearce L, Bunni J, McCarthy K, Hewitt J. Surgery in the older person: training needs for the provision of multidisciplinary care. Ann R Coll Surg Engl. 2016. https://doi.org/10.1308/rcsann. 2016.0180.

12.• Vilches-Moraga A, Rowley M, Fox J, et al. Emergency laparotomy in the older patient: factors predictive of 12-month mortality-Salford-POPS-GS. An observational study. Aging Clin Exp Res. 2020. https://doi.org/10.1007/s40520-020-01578-0. This is one of the first studies to report outcomes up to 12 months after emergency laparotomy in older patients as well as factors predicting poorer outcomes.

13. Chana P, Joy M, Casey N, et al. Cohort analysis of outcomes in 69490 emergency general surgical admissions across an international benchmarking collaborative. BMJ Open. 2017. https:// doi.org/10.1136/bmjopen-2016-014484.

14. Shah AA, Haider AH, Zogg CK, et al. National estimates of predictors of outcomes for emergency general surgery. In: Journal of Trauma and Acute Care Surgery. ; 2015. https://doi.org/10. 1097/TA.0000000000000555

15. Desserud KF, Veen T, Søreide K. Emergency general surgery in the geriatric patient. Br J Surg. 2016. https://doi.org/10.1002/bjs. 10044.

16. Wilkinson K. An age-old problem: care of older people undergoing surgery. Br J Hosp Med. 2011. https://doi.org/10.12968/ hmed.2011.72.3.126.

17. Clegg A, Young J, Iliffe S, Rikkert MO, Rockwood K. Frailty in elderly people. In The Lancet. 2013. https://doi.org/10.1016/ S0140-6736(12)62167-9.

18. McLean RC, McCallum IJD, Dixon S, O'Loughlin P. A 15-year retrospective analysis of the epidemiology and outcomes for elderly emergency general surgical admissions in the North East of England: a case for multidisciplinary geriatric input. Int J Surg. 2016. https://doi.org/10.1016/j.ijsu.2016.02.044.

19. Hewitt J, Carter B, McCarthy K, et al. Frailty predicts mortality in all emergency surgical admissions regardless of age. An observational study Age Ageing. 2019. https://doi.org/10.1093/ ageing/afy217.

20. Alder L, Mercer S, Carter N, Toh S, Knight B. Clinical frailty and its effect on the septuagenarian population after emergency laparotomy. Ann R Coll Surg Engl. 2021;103(3):180-5. https:// doi.org/10.1308/rcsann.2020.7028.

21. Vilches-Moraga A, Fox J. Geriatricians and the older emergency general surgical patient: proactive assessment and patient centred interventions. Salford-POP-GS Aging Clin Exp Res. 2018. https://doi.org/10.1007/s40520-017-0886-5.

22. Oliver CM, Walker E, Giannaris S, Grocott MPW, Moonesinghe SR. Risk assessment tools validated for patients undergoing emergency laparotomy: a systematic review. Br J Anaesth. 2015. https://doi.org/10.1093/bja/aev350.

23. Eamer G, Al-Amoodi MJH, Holroyd-Leduc J, Rolfson DB, Warkentin LM, Khadaroo RG. Review of risk assessment tools to predict morbidity and mortality in elderly surgical patients. Am J Surg. 2018. https://doi.org/10.1016/j.amjsurg.2018.04.006. A systematic review which examines the ability of different risk assessment tools to predict outcome after emergency surgery in elderly patients.

24. Copeland GP. The POSSUM system of surgical audit. Arch Surg. 2002;137(1):15-9. https://doi.org/10.1001/archsurg.137.1.15.

25. Stonelake S, Thomson P, Suggett N. Identification of the high risk emergency surgical patient: which risk prediction model should be used? Ann Med Surg. 2015;4(3):240-7. https://doi. org/10.1016/j.amsu.2015.07.004.

26. Knaus WA, Draper EA, Wagner DP, Zimmerman JE. APACHE II: a severity of disease classification system. Crit Care Med. 1985. https://doi.org/10.1097/00003246-198510000-00009.

27. Martin P, Statistician H. NELA risk adjustment model: recalibration of predictor coefficients, August 2020.

28. (No Title). https://data.nela.org.uk/riskcalculator/. Accessed January 31, 2021.

29. Fit for Frailty Part 1.; 2014.

30. Beech F, Brown A, Dhesi J, et al. Peri-operative care of the elderly 2014. Anaesthesia. 2014;69(SUPPL. 1):81-98. https:// doi.org/10.1111/anae.12524.

31. Griffiths R, Babu S, Dixon P, et al. Guideline by the Association of Anaesthetists. 2020. https://doi.org/10.1111/anae.15291

32. Chow WB, Rosenthal RA, Merkow RP, Ko CY, Esnaola NF. Optimal preoperative assessment of the geriatric surgical patient: a best practices guideline from the American College of Surgeons national surgical quality improvement program and the American geriatrics society. J Am Coll Surg. 2012;215(4):453-66. https://doi.org/10.1016/j.jamcollsurg. 2012.06.017. 
33. Partridge JSL, Harari D, Martin FC, Dhesi JK. The impact of pre-operative comprehensive geriatric assessment on postoperative outcomes in older patients undergoing scheduled surgery: a systematic review. Anaesthesia. 2014. https://doi.org/10.1111/ anae. 12494 .

34. Association of Anaesthetists T. Pre-operative assessment and patient preparation the role of the Anaesthetist 2 AAGBI SAFETY GUIDELINE.; 2010. www.aagbi.org. Accessed February 1, 2021.

35. Perioperative Care in Adults NICE Guideline.; 2020. www.nice. org.uk/guidance/ng180. Accessed February 1, 2021.

36. Stoneham M, Murray D, Foss N. Emergency surgery: the big three - abdominal aortic aneurysm, laparotomy and hip fracture. Anaesthesia. 2014. https://doi.org/10.1111/anae.12492.

37. Haynes AB, Weiser TG, Berry WR, et al. A surgical safety checklist to reduce morbidity and mortality in a global population. N Engl J Med. 2009. https://doi.org/10.1056/nejmsa0810 119.

38. McIlveen EC, Wright E, Shaw M, et al. A prospective cohort study characterising patients declined emergency laparotomy: survival in the 'No Lap' population. Anaesthesia. 2020;75(1):54-62. https://doi.org/10.1111/anae.14839.

39. Physiologic modification of the American Society of Anaesthesiology Score (ASA) for prediction of morbidity and mortality after emergency laparotomy. Internet J Surg. 2012. https://doi. org/10.5580/670

40. Lin HS, Watts JN, Peel NM, Hubbard RE. Frailty and post-operative outcomes in older surgical patients: a systematic review. BMC Geriatr. 2016. https://doi.org/10.1186/s12877-016-0329-8.

41. Cauley CE, Panizales MT, Reznor G, et al. Outcomes after emergency abdominal surgery in patients with advanced cancer: opportunities to reduce complications and improve palliative care. J Trauma Acute Care Surg. 2015. https://doi.org/10.1097/ TA.0000000000000764.

42. Yentis SM, Hartle AJ, Barker IR, et al. AAGBI: consent for anaesthesia 2017: Association of Anaesthetists of Great Britain and Ireland. Anaesthesia. 2017;72(1):93-105. https://doi.org/10. 1111/anae.13762.

43. Griffiths R, Beech F, Brown A, et al. Peri-operative care of the elderly 2014: association of anaesthetists of great britain and Ireland. Anaesthesia. 2014;69(SUPPL. 1):81-98. https://doi.org/ 10.1111/anae.12524.

44. ReSPECT for healthcare professionals I Resuscitation Council UK. https://www.resus.org.uk/respect/respect-healthcare-profe ssionals. Accessed March 24, 2021.

45. Guidance from the British Medical Association, the Resuscitation Council (UK) and the Royal College of Nursing.

46. White S, Griffiths R, Baxter M, et al. Guidelines for the perioperative care of people with dementia: guidelines from the Association of Anaesthetists. Anaesthesia. 2019;74(3):357-72. https://doi.org/10.1111/anae.14530.

47. Marik PE, Baram M, Vahid B. Does central venous pressure predict fluid responsiveness? Chest. 2008;134(1):172-8. https:// doi.org/10.1378/chest.07-2331.

48. Miller TE, Mythen M, Shaw AD, et al. Associations between perioperative fluid management and patient outcomes: a multicentre retrospective study. Br J Anaesth. 2020. https://doi.org/ 10.1016/j.bja.2020.10.031.

49. Rucklidge M, Beattie E. Rectus sheath catheter analgesia for patients undergoing laparotomy Learning objectives. 2018. https://doi.org/10.1016/j.bjae.2018.03.002

50. Tudor ECG, Yang W, Brown R, Mackey PM. Rectus sheath catheters provide equivalent analgesia to epidurals following laparotomy for colorectal surgery. Ann R Coll Surg Engl. 2015;97(7):530-3. https://doi.org/10.1308/rcsann.2015.0018.
51. Reynolds L, Beckmann J, Kurz A. Perioperative complications of hypothermia. Best Pract Res Clin Anaesthesiol. 2008;22(4):64557. https://doi.org/10.1016/j.bpa.2008.07.005.

52. Alleway R, Mayet S, Kelly K, et al. An Age Old Problem.

53. Simpson JC, Moonesinghe SR. Introduction to the postanaesthetic care unit. Perioper Med. 2013;2(1):5. https://doi.org/10. 1186/2047-0525-2-5.

54. Juhász EH, Iversen M, Samuelson A, Bäckström R, Nilsson U. Clinical practice and procedures for postoperative care in Sweden: results from a nationwide survey. J Perioper Pract. May 2020:175045892092535. https://doi.org/10.1177/1750458920 925355

55. Lee J, Cho YJ, Kim SJ, et al. Who dies after ICU discharge? Retrospective analysis of prognostic factors for in-hospital mortality of ICU survivors. J Korean Med Sci. 2017;32(3):528-33. https:// doi.org/10.3346/jkms.2017.32.3.528.

56. Saunders DI, Murray D, Pichel AC, Varley S, Peden CJ. Variations in mortality after emergency laparotomy: the first report of the UK emergency laparotomy network. Br J Anaesth. 2012;109(3):368-75. https://doi.org/10.1093/bja/aes165.

57. Soares M, Caruso P, Silva E, et al. Chracteristics and outcomes of patients with cancer requiring admission to intensive care units: a prospective multicenter study. Crit Care Med. 2010;38(1):9-15. https://doi.org/10.1097/CCM.0b013e3181 c0349e.

58. Sheetz KH, Krell RW, Englesbe MJ, Birkmeyer JD, Campbell DA, Ghaferi AA. The importance of the first complication: understanding failure to rescue after emergent surgery in the elderly. J Am Coll Surg. 2014;219(3):365-70. https://doi.org/ 10.1016/j.jamcollsurg.2014.02.035.

59. Ellis G, Whitehead MA, Robinson D, O'Neill D, Langhorne P. Comprehensive geriatric assessment for older adults admitted to hospital: meta-analysis of randomised controlled trials. BMJ. 2011;343(7832):1034. https://doi.org/10.1136/bmj.d6553.

60. Pound P, Sabin C, Ebrahim S. Observing the process of care: a stroke unit, elderly care unit and general medical ward compared. Age Ageing. 1999;28(5):433-40. https://doi.org/10.1093/ ageing/28.5.433.

61. Harari D, Hopper A, Dhesi J, Babic-Illman G, Lockwood L, Martin F. Proactive care of older people undergoing surgery ('POPS'): designing, embedding, evaluating and funding a comprehensive geriatric assessment service for older elective surgical patients. Age Ageing. 2007;36(2):190-6. https://doi.org/ 10.1093/ageing/afl163.

62. Grigoryan K V., Javedan H, Rudolph JL. Orthogeriatric care models and outcomes in hip fracture patients: a systematic review and meta-analysis. J Orthop Trauma. 2014;28(3). https:// doi.org/10.1097/BOT.0b013e3182a5a045

63. Overview / Hip fracture: management I Guidance I NICE.

64. Middleton M, Wan B, da Assunçāo R. Improving hip fracture outcomes with integrated orthogeriatric care: a comparison between two accepted orthogeriatric models. Age Ageing. 2016;46(3):465-70. https://doi.org/10.1093/ageing/afw232.

65. Richards T, Glendenning A, Benson D, Alexander S, Thati S. The independent patient factors that affect length of stay following hip fractures. Ann R Coll Surg Engl. 2018;100(7):556-62. https://doi.org/10.1308/rcsann.2018.0068.

66. Tarazona-Santabalbina FJ, Belenguer-Varea Á, Rovira E, CuestaPeredó D. Orthogeriatric care: improving patient outcomes. Clin Interv Aging. 2016;11:843-56. https://doi.org/10.2147/CIA. S72436.

67. Bachmann S, Finger C, Huss A, Egger M, Stuck AE, CloughGorr KM. Inpatient rehabilitation specifically designed for geriatric patients: systematic review and meta-analysis of randomised controlled trials. BMJ. 2010;340(7758):1230. https:// doi.org/10.1136/bmj.c1718. 
68. Burns JE, Yao J, Chalhoub D, Chen JJ, Summers RM. A machine learning algorithm to estimate sarcopenia on abdominal CT. Acad Radiol. 2020;27(3):311-20. https://doi.org/10.1016/j.acra. 2019.03.011.

69.• Boyd-Carson H, Gana T, Lockwood S, Murray D, Tierney GM. A review of surgical and peri-operative factors to consider in emergency laparotomy care. Anaesthesia. 2020. https://doi.org/ 10.1111/anae.14821. A recent review which summarises a number of strategies that are currently being explored with the aim of improving outcomes after emergency laparotomy, including ERAS pathways.

70. Lohsiriwat V. Enhanced recovery after surgery vs conventional care in emergency colorectal surgery. World J Gastroenterol. 2014. https://doi.org/10.3748/wjg.v20.i38.13950.

71. Wisely JC, Barclay KL. Effects of an enhanced recovery after surgery programme on emergency surgical patients. ANZ J Surg. 2016. https://doi.org/10.1111/ans.13465.

72. Shida D, Tagawa K, Inada K, et al. Modified enhanced recovery after surgery (ERAS) protocols for patients with obstructive colorectal cancer. BMC Surg. 2017. https://doi.org/10.1186/ s12893-017-0213-2.

73. Shang Y, Guo C, Zhang Di. Modified enhanced recovery after surgery protocols are beneficial for postoperative recovery for patients undergoing emergency surgery for obstructive colorectal cancer: a propensity score matching analysis. Med (United States). 2018. https://doi.org/10.1097/MD.0000000000012348

74. Verheijen PM, Vd Ven AWH, Davids PHP, Vd Wall BJM, Pronk A. Feasibility of enhanced recovery programme in various patient groups. Int J Colorectal Dis. 2012. https://doi.org/10. 1007/s00384-011-1336-Z.

75. Pederson JL, Padwal RS, Warkentin LM, Holroyd-Leduc JM, Wagg A, Khadaroo RG. The impact of delayed mobilization on postdischarge outcomes after emergency abdominal surgery: a prospective cohort study in older patients. PLoS One. 2020;15(11 November). https://doi.org/10.1371/journal.pone. 0241554

76. Barbas AS, Haney JC, Henry BV, Heflin MT, Lagoo SA. Development and implementation of a formalized geriatric surgery curriculum for general surgery residents. Gerontol Geriatr Educ. 2014. https://doi.org/10.1080/02701960.2013.879444.

Publisher's note Springer Nature remains neutral with regard to jurisdictional claims in published maps and institutional affiliations. 